\title{
グリコカリックス障害と臟器微小循環
}

射場敏明*

\section{Glycocalyx damage and microcirculatory disturbance}

\author{
Toshiaki IBA
}

\begin{abstract}
要約：血管内皮上に存在するグリコカリックスは，1）血球と血管内皮の摩擦を軽減し円滑な血液循環を維持 する，2）血管内腔の抗血栓性を維持する，3）血管透過性の調節を行う，4）血漿蛋白を保持するなどの重要な 役割を担っている。グリコカリックスは極めて跪弱な構造体であるがゆえに，様々な生体侵襲によって容易 に障害され，結果として生じる組織循環障害の成立に深く関わっている。グリコカリックスの急性障害は, これまで敗血症を中心に研究されてきたが, 最近になって外傷をはじめとする非感染性疾患においてもみら れることが注目され, endotheliopathy として多くの研究報告が行われているようになっている.今回はグリ コカリックス障害と微小循環障害の密接な関係について最近の知見を紹介する.
\end{abstract}

Key words: glycolcalyx, endothelial cell, syndecan, hyaluronan, heparan sulfate

\section{はじめに}

細胞の表面を覆う構造物であるグリコカリックス の存在は 1970 年前後から知られていたが，当初は 腸粘膜の絨毛から分泌される粘液として認知されて いた，続いて肺胞上皮やリンパ管における存在が確 認され，1980 年代になると血管内皮表面にもグリ コカリックスが存在することが明らかにされた。し かし血管内皮のグリコカリックスと疾病との関係が 注目されるようになったのは2000 年代になってか らで，以後直線的に研究報告数が増加して現在に 至っている。この跪弱な構造物は血流の存在下での み正常な状態を維持することが可能であり，血流の 低下や途絶に伴って速やかに減少する。また組織学 的検討に必要な固定, 染色の過程でも容易に破壊さ れることから，長らく観察が不可能であった。しか し 2010 年頃になると検体処理を工夫することに よって，また蛍光顕微鏡や電子顕微鏡を用いること によって形態観察が盛んに行われるようになってき

*責任者連絡先：

順天堂大学救急 ·災害医学

干 113-8421 東京都文京区本郷 2-1-1

Tel: 03-3813-3111, Fax: 03-3814-5431

E-mail: toshiiba@juntendo.ac.jp
た。最近ではさらに手技が改善されて一層詳細な観 察が可能になっている ${ }^{1)}$. また同時にシンデカンや ヒアルロン酸の濃度測定が一般研究室レベルでも可 能になり, 一気に研究は飛躍しつつある。本論文で はここ数年の進歩に焦点を絞って解説を行う.

\section{1. グリコカリックスの生理的機能}

血管内皮細胞の表面はプロテオグリカンやグリコ プロテインなどの膜結合部分(コアタンパク)を木の 幹とし， ペラン硫酸やコンドロイチン硫酸などの グリコサミノグリカン (糖鎖構造)を枝葉，そして幹 とは直接つながっていないツ夕に相当するヒアル ロン酸などの糖鎖，および水分とともにそれらに含 まれる血漿タンパクで構成される，グリコカリック スと称される構造体で覆われていることは以前本誌 の特集で紹介した通りである(図 $\mathbf{1})^{2)}$ 。このグリコ カリックスの生理的役割は，まず血球と血管内皮と の摩擦抵抗を軽減することであると考えられてい る。このことは糖鎖構造が海藻や魚の鱗のぬめりと 類似の構造であることから容易に想起される。流体 力学上, 循環血液中の血球細胞のうち, サイズの大 きい白血球は流れの速い中心部を, 次に赤血球は中 央部を，血小板のような小さな血球は流れの遅い血 


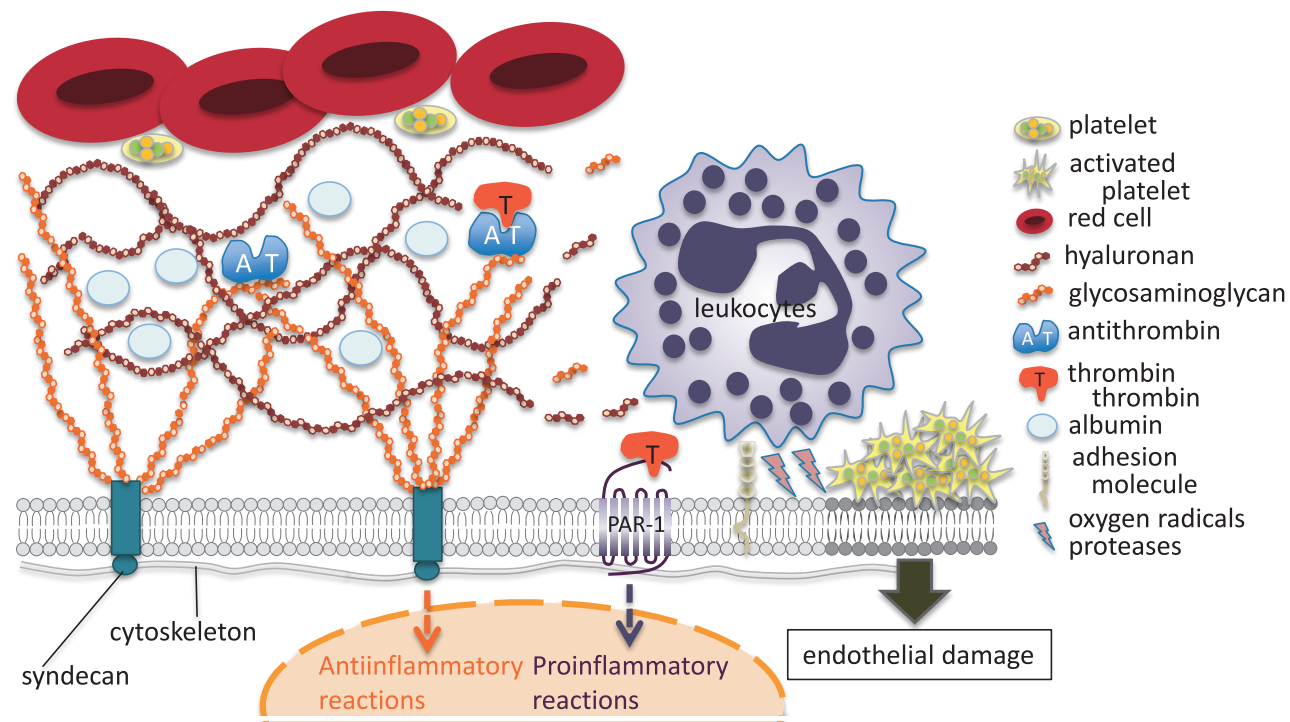

図 1 血管内皮におけるグリコカリックスの構造

血管内皮細胞状にはグリコカリックスと称される構造が存在する。グリコカリックスを構成しているのはシンデカンやグリ ピカンに代表される細胞膜に固定したプロテオグリカンと，接着分子などのグリコプロテイン，それにシンデカンに結合す るへパラン硫酸やコンドロイチン硫酸などの糖鎖構造 (glycosaminoglycan), およびシンデカンとは直接結合しない糖鎖であ るヒアルロン酸などである。プロテオグリカンの代表であるシンデカンは膜を貫通し，さらに細胞内の細胞骨格に結合して ずり応力などの機械的刺激を内皮細胞に情報として伝達している。そしてへパラン硫酸にはアンチトロンビンや成長因子, サイトカイン類が結合し，それぞれの結合刺激がコアプロテインの細胞内ドメインを介して，内皮細胞に情報伝達されるこ とが知られている.
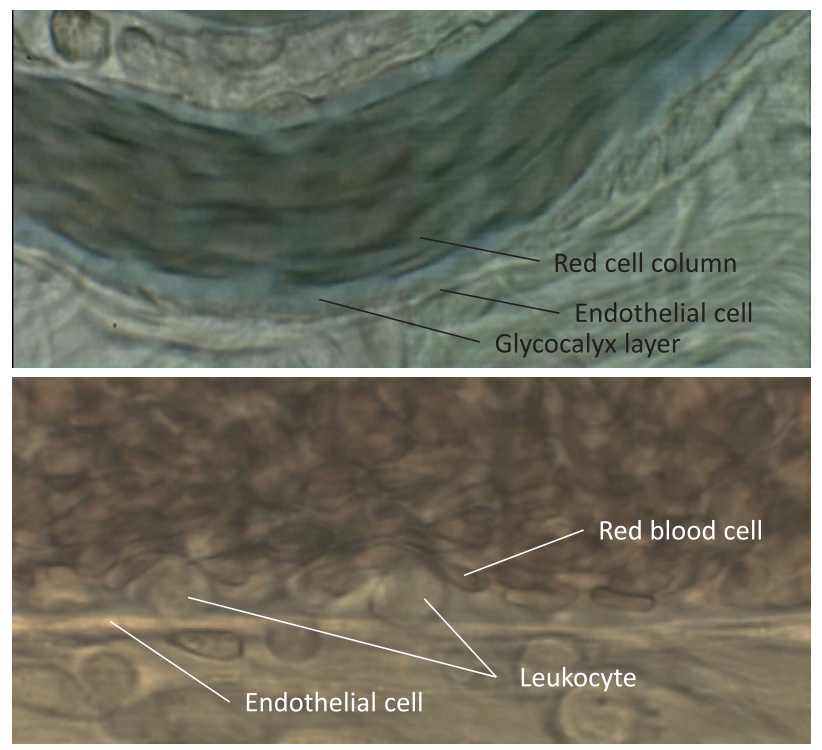

図 2 グリコカリックスの生体顕微鏡下観察

正常な毛細血管血流は赤血球円柱として観察されるが，円柱と血管内皮の間には一定のスペースが観察され，これがグリコ カリックスの厚みに相当する。上段：血管内にエバンスブルーを注入し，グリコカリックスを薄くブルーに染色している. 下段：炎症惹起モデルにおいては，グリコカリックス構造が菲薄化し，赤血球円柱との間隙が消失していることがわかる. また血球の移動速度が低下し，白血球が血管内皮上に接着しているところが観察できる. 
管辺縁部を移動することになるが，その際これらの 血球と血管内皮との直接的なコンタクトは血流抵抗 を増すことになるので，生体としてはできるだけこ れを避けたいところであろう（図 2)。グリコカリッ クスはいわゆる内皮をカバーするワックスとして存 在し，摩擦抵抗を減弱させてスムーズな血流維持に 機能していると考えられている。興味深いのは，白 血球系免疫細胞についてはグリコカリックスに含ま れるケモカインによって特定部位への遊走が刺激さ れるという報告がみられることで，内皮はグリコカ リックスを用いて必要な細胞を選択的に接着, 遊走 させていることが想像できる3 は癌細胞の転移との関連においても興味深いところ である。一方，木の幹に相当するシンデカンやグリ ピカンに代表されるプロテオグリカンは，アクチン に代表される内皮細胞内の細胞骨格と結合してお り，メカノセンサーとしてずり応力や血圧を感知し て細胞に情報伝達するアンテナの役割も担ってい る。そしてこれが血管収縮物質や一酸化窒素などの 産生調整を介して，血管収縮や拡張をはじめとする 内皮機能の制御や血管壁のリモデリングなどに深く 関わっていることが明らかにされている ${ }^{4,5)}$ 。さら に最近の研究によれば，グリコカリックスの糖鎖構 造は細胞膜の変形能にも関与しているらしく, 例え ば糖鎖構造のうちムチンは，マイクロベジクルの放 出などに関連しているとのことである ${ }^{6,7)}$ 。マイク ロベジクルは細胞から切り出される細胞膜に包まれ た，いわば細胞の断片であるが，細胞間の情報伝達 に機能していると考えられている。マイクロベジク ルの切り出しは, 細胞骨格の変化を契機にして細胞 膜の張り出しへとつながっていくが, 細胞表面にお けるムチンの存在はこの細胞膜の張り出し, 伸張を 助けているようである。また隣接する内皮細胞との 間, 内皮細胞裂 (endothelial cleft: ETC) に存在するグ リコカリックスは透過性の制御に重要な役割を担っ ており，水分や血漿タンパクの移動については，そ の存在抜きに単に圧格差や濃度勾配のみでは理解す ることができないことが明らかにされた。ささらに内 皮の最も大切な機能のひとつである抗血栓性の維持 に関しては，豊富に存在するへパラン硫酸とこれに 結合するアンチトロンビンの存在が注目されてお り, 現在活発に研究が進められている ${ }^{8,9)}$.

\section{2. バイオマーカーとしてのグリコカリックス}

グリコカリックスは跪弱な構造物であるがゆえ に，様々な刺激によって容易に剥離し，血中に遊離 する。そこでこのことを利用して血中を循環するグ リコカリックスの各要素を測定し, 病態の解明や重 症度診断に役立てようとする試みがある。たとえば 加齢, 糖尿病や動脈硬化などの血管変性を生じる慢 性疾患では，以前からこのような試みが行われて， その有用性が評価されてきたが, 最近では敗血症や 外傷, 虚血・再灌流障害などの急性疾患においても グリコカリックスの測定の重症度評価指標としての 有用性が報告されるようになり，血管バイオマー カーとしての注目度が増している ${ }^{10)}$ ，グリコカリッ クスが血中に遊離するメカニズムとしては, 敗血症 においては好中球をはじめとする白血球系細胞が活 性酸素種やエラスターゼに代表されるタンパク分解 酵素を放出してコアタンパクを分解し ${ }^{11)}$ ，また種々 の細胞から放出されるへパラナーゼやヒアルロニ ダーゼ，マトリックスメタロプロテイナーゼなどの 分解酵素はグリコサミノグリカンを分離するとされ ている ${ }^{12)}$. Reine $~^{13)}$ は，糖尿病や炎症性疾患にお いては IL-1 $\beta$ 刺激によって増加したマトリックスメ タロプロテイナーゼ 9 が糸球体のシンデカン 4 の 切り出しを行い, これが腎障害の発生と関連してい ることを報告している。さらにヒストンをはじめと する damage-associated molecular patterns (DAMPs) や 補体の活性化がグリコカリックスの障害に重要であ るとする報告もある ${ }^{14)}$ 。一方非感染性疾患として は，心肺停止後や外傷ショック，心血管手術などの 低灌流状態, あるいは高血糖や高血圧などの化学 的, 物理的刺激, さらには輸液負荷や昇圧剤の使用 といった治療の影響もグリコカリックスの障害を助 長することが知られている ${ }^{15,16)}$.

プロテオグリカンの主力をなすシンデカンファミ リーには，4つのサブタイプがあり，それぞれのシン デカンには分布特性があって，たとえば血管内皮細 胞の細胞間や基底膜側にはシンデカン $-1,-2,-4$ の発 現が認められる。このうちバイオマーカーとして最 も広く測定されているのがシンデカン-1で, 先に 述べたように循環不全や輸液，カテコラミン投与な どによる内皮障害にともなって血中レベルが増加す 
ることが知られている ${ }^{17,18)}$. シンデカン以外ではヒ アルロン酸やへパラン硫酸などにおいて同様に血管 内皮障害マーカーとしての有用性が期待されてい る。

上述したグリコカリックス構成成分の血中循環レ ベル測定以外では, side-stream dark field (SDF) imaging technique を用いた，舌下毛細血管血流の生体顕 微鏡下観察がある。グリコカリックスや血流の観察 手技として革新的かつ非侵襲，簡便であり，繰り返 し測定できるので病態の推移を観察することも可能 である。敗血症においては有用性が認められるとす る見解もあるが ${ }^{19)}$ ，一方で糖尿病においては，グリ コカリックス幅の低值はみられるものの，心血管リ スクとの関連は確認できなかったとする報告もあ $\eta^{20)}$ ，臨床的な評価は一定していない。また舌下の 血流が重要臓器の血流を反映しているのか否かにつ いて疑問を呈する研究者もおり，さらなる検討が必 要であろう ${ }^{21)}$.

血中を循環しているグリコカリックスには障害 マーカーとしての意義以外に何らかの役割があるか と問われるならば，その答えはイエスである。掕え らくグリコカリックスから逸脱した構成成分はその 再生にも用いられるであろうし22，また成長因子の 働きを修飾することや情報伝達物質としての役割も あることが想定されている ${ }^{23)}$ ，さらにはへパラン硫 酸はその高度の陰性荷電により, 陽性に带電してい るヒストンと結合して DAMPS としての組織障害性 を緩和することも報告されている24).

\section{3. 各種病態とグリコカリックス}

これまで慢性血管病変の発生機序に関しては未解 明の部分が多く残されてきたが，ここにきてグリコ カリックスとの関与が注目されるようになってきて いる．特に慢性血管炎症と捉えることもできる動脈 硬化性疾患においては，以前から，すでに硬化性病 変がみられる状態ではグリコカリックスが減少して いることが報告されていたが，ここにきてプラーク 形成以前の早い段階からグリコカリックスの障害が あることが報告され，グリコカリックス障害と動脈 硬化性病変の因果関係についても論じられるように なっている ${ }^{25)}$ 。また動脈血栓のみならず，静脈血栓
の発生に関してもグリコカリックス障害の関与が考 えられている。血管障害の絡みでは，腎障害との関 連が注目されており，糖尿病に打けるグリコカリッ クス障害と糸球体障害の関連が報告されている ${ }^{26)}$.

次に急性血管炎症である感染症とグリコカリック ス障害の関係については，以前からグリコカリック スが血管内皮障害の指標として有望視されていた。 Uchimido ら ${ }^{27)}$ は, 敗血症においてみられる血中や 尿中へのグリコカリックス構成成分の増加が血管透 過性や臓器障害，重症度と関連することを報告して いる。そして障害蔵器のうちでは，特に腎障害との 関連が多数報告されている ${ }^{28)}$ 。敗血症ではこのよう な感染に伴う急性血管炎症とともに，感染によって もたらされる高血糖状態，あるいは治療に用いられ る輸液の過多によってもグリコカリックスの破壊が もたらされることに注意する必要がある。一方でア ルブミンや新鮮凍結血漿はグリコカリックス保護的 に働くとされている。そしてグリコカリックスの障 害に伴う血管内凝固活性の克進状態は敗血症にしば しば合併する播種性血管内凝固の誘因や促進因子と なっていることは容易に想像される ${ }^{29)}$.

細菌による感染以外では，Yeo ら ${ }^{30)}$ がマラリアに おいてグリコカリックス破壊と重症度の間に関連が みられることを報告しており，またウイルス感染に おいても障害がみられることが報告され，これらの 感染症に抢いては上述の細菌感染における障害以外 のメカニズムの存在も想定される.

非感染性疾患である子癇前症は，高血圧やタンパ ク尿を主症状とする妊娠中合併症であるが，その発 症にグリコカリックス，さらに血管内皮障害が関 わっているとされている。 Wiles ら ${ }^{31)}$ は子痌前症の 患者でヒアルロン酸や血管内皮障害の指標である vascular cell adhesion molecule(VCAM)の血中レベル が増加することを報告し, 病態への関与を示唆して いる。 さらに Weissegerber ら ${ }^{32}$ もグリコカリックス は子痌前症の初期から障害されることを SDF imaging および血中シンデカン-1 やへパラン硫酸レベル の増加で検証している。また子瘉前症における腎障 害との関係についてはvan den Berg ら ${ }^{33)}$ が, 腎糸球 体のヒアルロン酸産生を抑制すると腎障害が生じる ことを報告しており，グリコカリックスと子痌，お よび腎障害発症の間には密接な関連があることがう 
かがえる。

そして最近最も注目を集めているのが外傷におけ るグリコカリックスの挙動である。外傷においては 大量出血, ショックによる循環障害や組織障害にと もなう DAMPs が，血管炎症や内皮障害を惹起し， シンデカン-1をはじめとするグリコカリックスの 構成要素が血中に逸脱することが知られており, 最 近では“endotheliopathy”という名称を用いて盛んに 報告されている ${ }^{34)}$.この endotheliopathyについては, 外傷初期にみられる線溶異常充進や凝固異常状態 (trauma-induced coagulopathy)への関与が考えられて おり，病態の解明が待たれるところである。ここで 注意しなければならないのは，一部の研究者は内皮 上から剝離して血中を循環するへパラン硫酸が凝固 抑制的(internal heparinization)に働き，これが同時に みられるトロンボモジュリンの逸脱によるプロテ イン C の活性化とあいまって, 外傷初期の出血傾 向に寄与していると解釈していることである ${ }^{35)}$ し し かし，挖らくこれは誤りで，このようなへパラン 硫酸やシンデカンに代表されるグリコカリックス成 分の増加や可溶性トロンボモジュリンの増加は, 血 管内皮機能障害を反映したものであり ${ }^{36)}$ ，実際には 血液凝固は充進した状態にあるものと考えられ $3^{37)}$.

以上に述ベたグリコカリックスの障害は非外傷性 ショックや循環停止症例, さらには臓器移植でみら れる虚血・再灌流後でも起こることが知られており, グリコカリックスの障害には循環障害が関わってい ることが示唆されている38).

\section{4. グリコカリックスの保護的治療}

グリコカリックスの病態への関与については多く の知見が得られているが, 治療に関する進展に目覚 ましいものがないのは残念である。グリコカリック スは血管リスクである高血圧や高脂血症, 高血糖の 影響を受けるため, 慢性血管炎症においてはこれら の障害因子を取り除くことがグリコカリックスの恒 常性維持に有効であろう ${ }^{39)}$. グリコカリックスは高 血糖時にみられる白血球の活性化状態において，お そらく血管内皮への白血球の接着を制御する役割を 担っていると考えられているが40), 一方で高血糖自
体はグリコカリックスを障害することが知られてい る ${ }^{41)}$, 高脂肪食についても同様にグリコカリックス 障害が起こり，これがマクロファージの血管への接 着を誘導し, 動脈硬化病変の形成につながっている という報告がある ${ }^{42)}$ 。このような障害に対しては高 血糖や高脂血症の是正による保護，予防以外の対策 としてグリコカリックスの切り出しを行うヒアルロ ニダーゼなどのタンパク分解酵素の活性を阻害する 試みも行われているが，注目すべきほどの効果はみ られていないようである.

治療によるグリコカリックス障害については，輸 液との関連が注目されている。輸液過多がグリコカ リックスの障害因子となることは先に述べたとおり であるが，膠質液を用いることによってその障害性 を緩和しようとする試みがある。実際に敗血症モデ ルに损いてはグリコカリックス保護効果と透過性の 維持効果が得られたことが報告されている ${ }^{43)}$.

グリコカリックスの重要な役割の一つが抗血栓性 の維持であり，グリコカリックスはその構造にヘパ リン類似物質を含むことから，ヘパリンをグリコカ リックス保護のために用いるという試みがある。へ パリンはグリコカリックス構造を安定化させ ${ }^{44)}$ ，ま た炎症における障害因子であるヒストンの障害性を 緩和する効果が期待される。しかしその有効性に関 していまだ一定の見解は得られていない45).

糖鎖構造に保持されるアルブミンをはじめとする 血漿蛋白については，構造の安定化がみられるとし てグリコカリックスの保護効果が期待され，それに 関する報告もみられる ${ }^{46)}$ 。一方, 生理的な抗凝固物 質であるアンチトロンビンについては，これとは別 の機序によるグリコカリックスの保護効果が期待さ れている。アンチトロンビンは，ヘパリンと共通の 構造であるへパラン硫酸のペンタサッカライドに結 合することによって血管内皮表面の抗凝固活性を高 めるとともに, グリコカリックス構造を安定化させ ることが報告されている ${ }^{47)}$.

\section{おわりに}

血管障害は様々な疾患と関連しており, 中でも内 皮の重要な構成要素であるグリコカリックスに関す る研究は急速な進展をみせている。 今回は 2016 年 
に組まれた前回の特集以降の発表を中心に紹介させ ていただいたが, PubMed で glycocalyx をキーワー ド検索すると 2017 年は 150 程度であったヒット件 数が 2018 年には 228 件と 1.5 倍を超え，2019 年は 7 月末の時点ですでに 160 件と加速度的に増加して いる状況である。そしてこの間，研究テーマは病態 生理からバイオマーカーとしての有用性にシフトし ているが，治療に関してはいまだ報告が少なく，今 後の課題であると考える.

\section{著者の利益相反 $(\mathrm{COI})$ の開示 :}

研究費 (受託研究, 共同研究, 寄付金等) (JIMRO, $\mathrm{JB})$

\section{文献}

1) Okada H, Takemura G, Suzuki K, Oda K, Takada C, Hotta Y, Miyazaki N, Tsujimoto A, Muraki I, Ando Y, Zaikokuji R, Matsumoto A, Kitagaki H, Tamaoki Y, Usui T, Doi T, Yoshida T, Yoshida S, Ushikoshi H, Toyoda I, Ogura S: Three-dimensional ultrastructure of capillary endothelial glycocalyx under normal and experimental endotoxemic conditions. Crit Care 21: $261,2017$.

2）射場敏明：グリコカリクスが関与する血管内腔の抗血 栓性とその障害。血栓止血誌 $27 ： 444-449,2016$.

3) Graham GJ, Handel TM, Proudfoot AEI: Leukocyte Adhesion: Reconceptualizing Chemokine Presentation by Glycosaminoglycans. Trends Immunol 40: 472-481, 2019.

4) Sáez P, Gallo D, Morbiducci U: Mechanotransmission of haemodynamic forces by the endothelial glycocalyx in a fullscale arterial model. R Soc Open Sci 6: 190607, 2019.

5) Bartosch AMW, Mathews R, Tarbell JM: Endothelial Glycocalyx-Mediated Nitric Oxide Production in Response to Selective AFM Pulling. Biophys J 113: 101-108, 2017.

6) Strzyz P: Bend it like glycocalyx. Nat Rev Mol Cell Biol 20: 388, 2019, doi: 10.1038/s41580-019-0142-2.

7) Shurer CR, Kuo JC, Roberts LM, Gandhi JG, Colville MJ, Enoki TA, Pan H, Su J, Noble JM, Hollander MJ, O'Donnell JP, Yin R, Pedram K, Möckl L, Kourkoutis LF, Moerner WE, Bertozzi CR, Feigenson GW, Reesink HL, Paszek MJ: Physical principles of membrane shape regulation by the glycocalyx. Cell 177: 1757-1770.e21, 2019.

8) Iba T, Levy JH: Derangement of the endothelial glycocalyx in sepsis. J Thromb Haemost 17: 283-294, 2019.

9) Iba T, Sasaki T, Ohshima K, Sato K, Nagaoka I, Thachil J: The comparison of the protective effects of $\alpha$-and $\beta$-antithrombin against vascular endothelial cell damage induced by histone in vitro. TH Open 1: e3-e10, 2017.

10) Hippensteel JA, Uchimido R, Tyler PD, Burke RC, Han X, Zhang F, McMurtry SA, Colbert JF, Lindsell CJ, Angus DC, Kellum JA, Yealy DM, Linhardt RJ, Shapiro NI, Schmidt EP: Intravenous fluid resuscitation is associated with septic endo- thelial glycocalyx degradation. Crit Care 23: 259, 2019.

11) Suzuki K, Okada H, Takemura G, Takada C, Kuroda A, Yano H, Zaikokuji R, Morishita K, Tomita H, Oda K, Matsuo S, Uchida A, Fukuta T, Sampei S, Miyazaki N, Kawaguchi T, Watanabe T, Yoshida T, Ushikoshi H, Yoshida S, Maekawa Y, Ogura S: Neutrophil elastase damages the pulmonary endothelial glycocalyx in lipopolysaccharide-induced experimental endotoxemia. Am J Pathol 189: 1526-1535, 2019.

12) Sieve I, Münster-Kühnel AK, Hilfiker-Kleiner D: Regulation and function of endothelial glycocalyx layer in vascular diseases. Vascul Pharmacol 100: 26-33, 2018.

13) Reine TM, Lanzalaco F, Kristiansen O, Enget AR, Satchell S, Jenssen TG, Kolset SO: Matrix metalloproteinase-9 mediated shedding of syndecan-4 in glomerular endothelial cells. Microcirculation e12534, doi: 10.1111/micc.12534, 2019.

14) Bongoni AK, Lu B, McRae JL, Salvaris EJ, Toonen EJM, Vikstrom I, Baz Morelli A, Pearse MJ, Cowan PJ: Complement-mediated damage to the glycocalyx plays a role in renal ischemia-reperfusion injury in mice. Transplant Direct 5: e341, 2019.

15) Milford EM, Reade MC: Resuscitation fluid choices to preserve the endothelial glycocalyx. Crit Care 23: 77, 2019.

16) Gonzalez Rodriguez E, Ostrowski SR, Cardenas JC, Baer LA, Tomasek JS, Henriksen HH, Stensballe J, Cotton BA, Holcomb JB, Johansson PI, Wade CE: Syndecan-1: A quantitative marker for the endotheliopathy of trauma. J Am Coll Surg 225: 419-427, 2017.

17) Ostrowski SR, Haase N, Müller RB, Møller MH, Pott FC, Perner A, Johansson PI: Association between biomarkers of endothelial injury and hypocoagulability in patients with severe sepsis: a prospective study. Crit Care 19: 191, 2015.

18) Bogner-Flatz V, Braunstein M, Ocker LE, Kusmenkov T, Tschoep J, Ney L, Böcker W, Annecke T: On-the-scene hyaluronan and syndecan-1 serum concentrations and outcome after cardiac arrest and resuscitation. Mediators Inflamm doi: 10.1155/2019/80701619, 2019.

19) Rovas A, Seidel LM, Vink H, Pohlkötter T, Pavenstädt H, Ertmer C, Hessler M, Kümpers P: Association of sublingual microcirculation parameters and endothelial glycocalyx dimensions in resuscitated sepsis. Crit Care 23: 260, 2019.

20) Valerio L, Peters RJ, Zwinderman AH, Pinto-Sietsma SJ: Sublingual endothelial glycocalyx and atherosclerosis. A cross-sectional study. PLoS ONE 14: e0213097, 2019.

21) De Backer D: Is microcirculatory assessment ready for regular use in clinical practice? Curr Opin Crit Care 25: 280-284, 2019.

22) Mensah SA, Cheng MJ, Homayoni H, Plouffe BD, Coury AJ, Ebong EE: Regeneration of glycocalyx by heparan sulfate and sphingosine 1-phosphate restores inter-endothelial communication. PLoS ONE 12: e0186116, 2017.

23) Oshima K, Haeger SM, Hippensteel JA, Herson PS, Schmidt EP: More than a biomarker: the systemic consequences of heparan sulfate fragments released during endothelial surface layer degradation (2017 Grover Conference Series). Pulm Circ 8: doi: 10.1177/2045893217745786, 2018.

24) Zhang Y, Haeger SM, Yang Y, Dailey KL, Ford JA, Schmidt EP: Circulating heparan sulfate fragments attenuate histone- 
induced lung injury independently of histone binding. shock 48: 666-673, 2017.

25) Bar A, Targosz-Korecka M, Suraj J, Proniewski B, Jasztal A, Marczyk B, Sternak M, Przybyło M, Kurpińska A, Walczak M, Kostogrys RB, Szymonski M, Chlopicki S: Degradation of glycocalyx and multiple manifestations of endothelial dysfunction coincide in the early phase of endothelial dysfunction before atherosclerotic plaque development in apolipoprotein E/low-density lipoprotein receptor-deficient mice. J Am Heart Assoc 8: e011171, 2019.

26) Ndisang JF: Glomerular endothelium and its impact on glomerular filtration barrier in diabetes: Are the gaps still illusive? Curr Med Chem 25: 1525-1529, 2018.

27) Uchimido R, Schmidt EP, Shapiro NI: The glycocalyx: a novel diagnostic and therapeutic target in sepsis. Crit Care 23: 16, 2019.

28) Song JW, Zullo J, Lipphardt M, Dragovich M, Zhang FX, Fu B, Goligorsky MS: Endothelial glycocalyx-the battleground for complications of sepsis and kidney injury. Nephrol Dial Transplant 33: 203-211, 2018.

29) Ikeda M, Matsumoto H, Ogura H, Hirose T, Shimizu K, Yamamoto K, Maruyama I, Shimazu T: Circulating syndecan-1 predicts the development of disseminated intravascular coagulation in patients with sepsis. J Crit Care 43: 48-53, 2018.

30) Yeo TW, Weinberg JB, Lampah DA, Kenangalem E, Bush P, Chen Y, Price RN, Young S, Zhang HY, Millington D, Granger DL, Anstey NM: Glycocalyx breakdown is associated wih severe disease and fatal outcome in plasmodium falciparum Malaria. Clin Infect Dis doi: 10.1093/cid/ciz038, 2019.

31) Wiles K, Bramham K, Seed PT, Kurlak LO, Mistry HD, Nelson-Piercy C, Lightstone L, Chappell LC: Diagnostic indicators of superimposed preeclampsia in women with CKD. Kidney Int Rep 4: 842-853, 2019.

32) Weissgerber TL, Garcia-Valencia O, Milic NM, Codsi E, Cubro H, Nath MC, White WM, Nath KA, Garovic VD: Early onset preeclampsia is associated with glycocalyx degradation and reduced microvascular Perfusion. J Am Heart Assoc 8: e010647, 2019.

33) van den Berg BM, Wang G, Boels MGS, Avramut MC, Jansen E, Sol WMPJ, Lebrin F, Jan van Zonneveld A, de Koning EJP, Vink H, Gröne HJ, Carmeliet P, van der Vlag J, Rabelink TJ: Glomerular function and structural integrity depend on hyaluronan synthesis by glomerular endothelium. J Am Soc Nephrol pii: ASN.2019020192, 2019.

34) Henriksen $\mathrm{HH}$, McGarrity S, SigurĐardóttir RS, Nemkov T, D'Alessandro A, Palsson BO, Stensballe J, Wade CE, Rolfsson Ó, Johansson PI: Metabolic systems analysis of shock-induced endotheliopathy (SHINE) in trauma: A new research paradigm. Ann Surg doi: 10.1097/SLA.0000000000003307, 2019.

35) Albert V, Subramanian A, Agrawal D, Pati HP, Gupta SD, Mukhopadhyay AK: Acute traumatic endotheliopathy in iso- lated severe brain injury and its impact on clinical outcome. Med Sci 6: pii: E5, 2018.

36) Gonzalez Rodriguez E, Cardenas JC, Cox CS, Kitagawa RS, Stensballe J, Holcomb JB, Johansson PI, Wade CE: Traumatic brain injury is associated with increased syndecan-1 shedding in severely injured patients. Scand J Trauma Resusc Emerg Med 26: 102, 2018.

37) Gando S, Hayakawa M: Pathophysiology of trauma-induced coagulopathy and management of critical bleeding requiring massive transfusion. Semin Thromb Hemost 42: 155-165, 2016.

38) Guerci P, Ergin B, Uz Z, Ince Y, Westphal M, Heger M, Ince C: Glycocalyx degradation is independent of vascular barrier permeability increase in nontraumatic hemorrhagic shock in rats. Anesth Analg 129: 598-607, 2019.

39) Triantafyllidi H, Benas D, Vlachos S, Vlastos D, Pavlidis G, Schoinas A, Varoudi M, Birmpa D, Moutsatsou P, Lekakis J, Ikonomidis I: HDL cholesterol levels and endothelial glycocalyx integrity in treated hypertensive patients. J Clin Hypertens 20: 1615-1623, 2018.

40) Dogné S, Flamion B, Caron N: Endothelial glycocalyx as a shield against diabetic vascular complications: Involvement of hyaluronan and hyaluronidases. Arterioscler Thromb Vasc Biol 38: 1427-1439, 2018.

41) Targosz-Korecka M, Jaglarz M, Malek-Zietek KE, Gregorius A, Zakrzewska A, Sitek B, Rajfur Z, Chlopicki S, Szymonski M: AFM-based detection of glycocalyx degradation and endothelial stiffening in the $\mathrm{db} / \mathrm{db}$ mouse model of diabetes. Sci Rep 7: 15951, 2017.

42) Mitra R, Qiao J, Madhavan S, O'Neil GL, Ritchie B, Kulkarni P, Sridhar S, van de Ven AL, Kemmerling EMC, Ferris C, Hamilton JA, Ebong EE: The comparative effects of high fat diet or disturbed blood flow on glycocalyx integrity and vascular inflammation. Transl Med Commun 3: 2018.

43) Margraf A, Herter JM, Kühne K, Stadtmann A, Ermert T, Wenk M, Meersch M, Van Aken H, Zarbock A, Rossaint J: 6\% Hydroxyethyl starch (HES 130/0.4) diminishes glycocalyx degradation and decreases vascular permeability during systemic and pulmonary inflammation in mice. Crit Care 22: 111, 2018.

44) Lipowsky HH, Lescanic A: Inhibition of inflammation induced shedding of the endothelial glycocalyx with low molecular weight heparin. Microvasc Res 112: 72-78, 2017.

45) Li X, Ma X: The role of heparin in sepsis: much more than just an anticoagulant. Br J Haematol 179: 389-398, 2017.

46) Barelli S, Alberio L: The role of plasma transfusion in massive bleeding: Protecting the endothelial glycocalyx? Front Med 5: 91, 2018.

47) Iba T, Levy JH, Hirota T, Hiki M, Sato K, Murakami T, Nagaoka I: Protection of the endothelial glycocalyx by antithrombin in an endotoxin-induced rat model of sepsis. Thromb Res 171: 1-6, 2018. 